\title{
Creativity at the Crossroad Creative Education as Moral Education?
}

\author{
Sara Nosari \\ Dept. of Philosophy and Sciences of Education, University of Study, Turin, Italy \\ Email: sara.nosari@unito.it
}

Received 2012

\begin{abstract}
The man's action, thanks to its creative capacities, gave a new order to the reality: the "created reality" does not present simply a different order, but is an authentic transformation. Which criteria had directed this transformation? Which will be the criteria of future transformation? The paper presents two possible ideas about creativity and argues in favor of a creative action educated and directed by an ethical criteria.
\end{abstract}

Keywords: Component; Human Being; Design; Judgment

\section{Introduction}

In the 1970s, Hans Jonas denounced the danger that threatened the existence in the world: the effective range of man's action had terminated to be small. The power to act, amplified by the advancement of technology, was become able to modify the state of things. The long run of consequences was turning the "immutable" state of Nature: man's action was creating a "second nature" that did not respond to the law of Nature. But not only. The chancing seemed endless.

It was necessary to know the causal scale of man's action. However, it was not only a "knowledge question": it was not enough that the technological knowledge became a "predictive knowledge". The power to act of the technological intervention posed an "ethical question".

The range ever more extended - perhaps without limits - of man's action went so far in wandering to everywhere. Without direction, the capacity to change the essential immutability of Nature and the order of things put into play the proper life of the man. For this raison, in light of modern technological power, man's action could not more be "ethically neutral" [1].

The denunciation is still current today. Indeed, this denunciation was not considered seriously and it has become an emergency. Man is ever more a spectator - not the real protagonist of his creative capacity [2]. The successes of technological action have not - often - a "reference" that gives them a position and a value: they are beyond of Man and risk to alienate the human existence.

The actual human identity, however, is not alienated by too much technology: the problem is that the technological intervention has not questions about the final destination of its action. Each discourse on possibilities of man's action is about its functions or its applications.

It is necessary redesign the man's action capacities in a "vision of the world" where everything has a position, a value and a relation with the limits of the world, but - above all - a final direction.

\section{An Instrumental Creativity}

The actual translation of creative capacity presents a particu- lar condition. The attention is focused on the endless of changing. The creative action - with the power of its technological version - works with the aim to produce a continuous change.

This "productive" creativity enhances its capacity of transformation, but sets aside its capacity of improvement. The creative action not always realizes the better transformation: its intervention does not pose the question what is better (or worse). It is become an instrumental creativity having the function to produce new changes.

This creative action presents two main consequences: the first concerns the action's subject; le second, the action's results.

A productive creativity transforms the subject in a "subject of production”. The man is not more the changing author, but a changing maker.

Also, a productive creativity transforms the results in effects without control. The limit of this creative action is the limitlessness and, above all, the possible immortality of its effects [3].

The creative capacity serves today to invent many means. But means to achieve what? The authentic power of creativity is to invent final aims.

So it is necessary to consider the creativity not only as an instrumental capacity.

\section{Creativity as Original Capasity}

\section{A Free Action}

The man's action is a particular process. The changing caused by human intervention is not simply the necessary consequence of previous conditions: it is the expression of an act of freedom. In fact, man can do else: he is not bound to a specific result (how it happens in Nature) because he is capable to enlarging the boundaries of natural continuity and going beyond.

When he acts, man initiates, begins, puts in motion something [4]. This start can not be fully anticipated by the previous events because it depends on the man's initiative. Man - only the man - is capable to take the initiative. Man's action has an only one cause: the man that did it.

Each man is formed by this original capacity: he is capable to 
commence an action that could not happen else. Through the action of this extraordinaire capacity, the reality is not more only how it is, but it becomes how it could be [5].

The creative action can not be confused with an act of explanation. Thanks to the creative action, the changing can follow a "free" direction, namely a direction that the reality could not take without the free "interpretation" of each man.

\section{An Unpredictable Action}

Concretely, the creative capacity that characterizes the human action translates in the creation of something new e and unexpected. The action that transforms the order of reality, creating a "different" reality, is an unpredictable action.

The creative action has not predetermined contents. The creativity does not allow anticipation: this action could not be an human action if anticipated. Moreover it does not allow computation: man could not be the author of his action if computed.

Man becomes interpreter of reality creating a new and unpredictable version of reality: his interpretation does not just give a different order to things, but it gives them a sense and a value. The created order is vision of the world where every thing has a position and a meaning (not only a function).

\section{A Perspective Action}

The renewal generated by human creativity can not be arbitrary. Creativity is not even a choice between many and indistinct possibilities. By acting, man gives to the reality of things a perspective. The chosen perspective has to be an authentic improvement. But which is the criteria of authenticity that must direct the creative action?

Being human has to be an human being. By creating, man does not repeat a predetermined sequences of acts: his interpretation has to return the reality giving it a human version, namely a significance.

This assignment of signification is an act of responsibility. In fact, the interpretation by which man creates is necessarily a response: it responds of humanity being but responds to each man too.

By reason of this act of interpretation, creativity is always a judgment: this capacity recognizes the potential value into reality and takes a position to realize it. It is the reason in why the creativity acts as cause for. Man's action is the only changing capable to act in the name of.

Consequently, creativity is necessarily to be considered as decision and engagement too: it acts to put in place the recognized value and engages in the taken direction.

Man's action is not authentically creative when it does not respond, not decide, not engage: the action that is not responsible for human being is not authentically creative. Each man's action must take a human direction.

This act, however, is a capacity: therefore it remains a possibility. Its effective exercise is an educational task.

\section{Education for Creativity}

\section{The Practice of Design}

The creative changing is demand, research, design. The human changing is, at first, a form of thought that constantly asks: who? What? Where? At what time? How? Why?

Il is necessary to educate to the demand. But the education has to educate to the most important demand: who is man? Nevertheless, the educational task is not solved in an act of cognition: the problem is not simply to know what or how is the man.

The education has the task of cultivating the sensitivity toward human being: the attention is a fundamental practice in the creation of a human change. A inattentive action is insidious and devastating because it makes the change as a deformation. Only an attentive thought can research and recognize the man's possibilities: being human is not a foregone conclusion, but it is novelty, surprise and also mystery [6].

Man must respond to these questions, but his creative action is not only a response: it is always a proposal because it design the image that will be the direction of human being. Design means, de facto, to choose the human destiny.

For this reason, the education for creativity must exercise man's action in situations where it is necessary a choice. But every choice is a judgment.

\section{The Practice of Judgment}

The changing is truly creative only when man's action gives to the changing a direction that meets the human sense. It becomes important, as consequence, to exercise the man's capacity to judgment. The education must assume - once again - the task to build this capacity.

This is what William Heard Kilpatrick asked since 1926 when he wrote the pages of Education for at a Changing Civilization, in reply to the incessant scientific progress: If the progress of science is, as it seems, a growing tendency to criticize and to question institutions accepted until then, follows the demand that education shall if possible increase the capacity to judge. Otherwise, destruction may flourish the expense of construction [7].

The judgment capacity that the educational process has to exercise is the capacity to distinguish between what "evidence" and what "denies" the human sense.

However, the exercise of judgment is a very difficult practice. The judgment that gives form to the creative action is the act that gives commencement to the creative action: the judgment is the beginning and, as such, indicates the direction. Consequently the education for creativity is, first of all, the space for the reflection and the research of a unitary orientation.

If the creativity starts through the practice of judgment, it means to transform the creative action in a real discipline. The creative process must be accomplished - all the time - as a process of fidelity, consistency and courage.

\section{The Future of Creativity}

\section{The Imperative}

For man, creativity is not just a possibility, but a necessity: the human essence is in the creative action, in an action that redesigns the being human giving a sense, namely a different direction from the course of the Nature. In fact, if the change does not imply a creative direction, it remains mere extension of the past. If the change is just an extension of the past, it can not design a role, a position and a sense for the being human,

Creativity is a necessity that has the power of the imperative. Only a creative direction raises the man from a life of repetition. Only a creative direction can open the space and the time for an action that designs and realizes the human being. In fact, the 
man that does not act creatively loses everything, that is, he loses the possibility to live freely and to give a meaning to own existence in the world.

The story of each man depends from creativity. The history of humanity depends from the men's creative actions.

However, it is not sufficient the imperative of creativity to realize a new reality. It necessary to desire to realize the reality designed by the creative action. The man can realize a new world just when he desires sincerely the change and believes in what he desires.

Then, it is necessary a "credo" to transform the succession of the changes in the realization of a design.

\section{The Croassroad}

Every change has to be marked by a direction: the direction is implied in the same idea of change. How can we design the human direction today? The choice can not be neutral because the question is an existential question.

This neutrality is the problem of technology today. Of course, the technological intervention is one of the most significant expression of man's creativity. However, it is thought and researched to be "ready to use": it follows a freedom of the moment or a meaning appropriate to the situation. This to be "usable" has always a deadline and causes a untrue freedom and a evanescent meaning. Consequently, it is not a technology really compromised with an idea of human destiny.

It becomes urgent that the technological expression of creativity compromises itself indicating clearly for which human being intends to act.

Which human identity will the creative action propose? Which profile will the future image of human being have? In real terms, who will be the author and the receiver of the im- provement realized by the creative action?

The different responses meet themselves at a crossroad: the direction of creative action is marked by an image of human being that can be "individual" or "collective".

If the creativity will follow an individual direction, the creative action will become a competition: it will end with the victory and the supremacy of only one.

If the creativity will follow a collective direction, the creative action will become a collaboration: it will work to a result to share with everyone.

These directions present two radically different images of humanity and two radically different destinies of human existence: the future generations wait for our judgment and our design.

\section{REFERENCES}

H. Jonas, The Imperative of Responsibility. In Search of an Ethica for the Techological Age,, Chicago, The University of Chicago Press, 1984, pp. 3-9.

G.O. Longo, Homo Technologicus, Rome, Meltemi, 2005, pp. 14-17.,

G. Anders, Gewald. Ja oder nein. Eine notwendige Diskussion (tr. Violence: Yes or No. A Necessary Discussion), Munich, Knaur, 1987.

H. Arendt, The Human Condition, Chicago, University of Chicago Press, 1998, second edition, p. 128.

J. Dewey, The Need for a Recovery of Philosophy in J. Dewey (et al.), Creative Intelligence. Essays in the Pragmatic Attitude, New York, H. Holt and Company, 1917,. p. 36.

A. Heschel, Who in man?, Stanford, Stabford University Press, 1965, p. 37.

W.H. Kilpatrick, Education for a Changing Civilization, New York, The Macmillan Company, 1926, p. 67. 